\title{
Sudden stops of international fund flows: Occurrence and magnitude
}

\author{
Suxiao Li, Jakob de Haan, Bert Scholtens
}

\begin{tabular}{|c|c|}
\hline Date of deposit & $31 / 01 / 2019$ \\
\hline Document version & Author's accepted manuscript \\
\hline Access rights & $\begin{array}{l}\text { Copyright (c) } 2018, \text { John Wiley } \& \text { Sons Ltd. This work is made } \\
\text { available online in accordance with the publisher's policies. This is } \\
\text { the author created, accepted version manuscript following peer } \\
\text { review and may differ slightly from the final published version. }\end{array}$ \\
\hline $\begin{array}{l}\text { Citation for } \\
\text { published version }\end{array}$ & $\begin{array}{l}\text { Li, S., de Haan, J., \& Scholtens, L. J. R. (2019). Sudden stops of } \\
\text { international fund flows: Occurrence and magnitude. Review of } \\
\text { International Economics, 27(1), 468-497. }\end{array}$ \\
\hline $\begin{array}{l}\text { Link to published } \\
\text { version }\end{array}$ & https://doi.org/10.1111/roie.12385 \\
\hline
\end{tabular}

Full metadata for this item is available in St Andrews Research

Repository at: https://research-repository.st-andrews.ac.uk/

\section{St Andrews Research Repository}




\title{
Sudden Stops of International Fund Flows: \\ What Drives Their Occurrence and Magnitude?
}

Accepted version 1 November 2018

\begin{abstract}
Using data of 65 countries from January 2000 (2008) to June 2015, we examine the covariates of sudden stops in fund equity and bond flows. Our results suggest that global, contagion and domestic factors are all important in determining the likelihood of sudden stops. For sudden stops in equity flows, global factors play a more important role in high-income countries. For sudden stops in bond flows, global variables are the most important covariates in emerging countries, whereas domestic variables play a more important role in high-income countries. We also find that global and contagion factors are correlated to the magnitude of sudden stops.
\end{abstract}

Keywords: international fund flows, sudden stops, push and pull factors, contagion JEL classification: E32, F30, F32, G15, G23 


\section{Introduction}

Edwards (2004, p. 59) defines a sudden stop as "an abrupt and major reduction in capital inflows to a country that has been receiving large volumes of foreign capital". Sudden stops are associated with several financial and economic disruptions, such as a depreciation of the real exchange rate (Calvo, 1998; Calvo and Reinhart, 2000), higher costs of external finance (Calvo et al., 2004; Calvo and Talvi, 2005), an increase in non-performing bank loans (Calvo et al., 2004), and banking and currency crises (de Mello et al., 2012; Calderón and Kubota, 2013). If a country is cut off from international capital markets, investments and economic growth will drop (Calvo and Talvi, 2005). Edwards (2007) shows that sudden stops lead to an average decline of $4 \%$ in GDP growth. This collapse in real activity is usually accompanied by increased unemployment (Rothenberg and Warnock, 2011; Cowan and Raddatz, 2013).

Several papers have examined the drivers of sudden stops (cf. Edwards, 2007; Calvo et al., 2008; Agosin and Huaita, 2012; Forbes and Warnock, 2012; Calderón and Kubota, 2013; Cowan and Raddatz, 2013). These studies focus on stops of total international capital flows. In contrast, this paper examines sudden stops of international fund flows. International fund flows are cross-border investments in bond and equity markets by global funds, including mutual funds, exchange traded funds (ETFs), closed-end funds, insurance-linked funds, and hedge funds (Li et al., 2015). Our data comes from Emerging Portfolio Fund Research (EPFR) Global Database, which tracks the asset allocation of more than 62,500 funds (as of September 2014). ${ }^{1}$ As shown in Figure 1, from 2000 to 2015, assets under management by global funds (covered by the EPFR Global Database) increased more than 150 times, expanding from 0.15 trillion US dollars to 25 trillion US dollars. In 2015, their assets accounted for 35\% of world GDP. Furthermore, as they are short-term investments their volatility is generally higher than that of other types of capital flows (Calvo, 1998). To illustrate this, Table 1 presents the standard deviation of different types of capital flows for selected countries. Levchenko and Mauro (2007), Agosin and Huaita (2012) show that fund flows are more susceptible to reversal when investors get new information. As shown in Figure 2, most countries faced outflows in 2008 when the U.S. subprime crisis hit the world. While in 2010 only Western European countries experienced fund outflows, in 2011 all countries experienced fund outflows. This suggests that fund flows play an important role in the transmission of shocks (Jinjarak et al., 2011; Raddatz and Schmukler, 2012). Given all this,

\footnotetext{
1 The database tracks around 98\% of emerging market equity funds, over 95\% of ETF assets globally, around 90\% of funds in the US, 85\%-90\% of Canadian mutual funds, and 70\%-75\% of funds in developed European markets. Some previous studies also used this database (cf. Jinjarak et al., 2011; Fratzscher, 2012; Raddatz and Schmukler, 2012; Yeyati and Williams, 2012; and Puy, 2016).
} 
examining sudden stops of fund flows is relevant, both from an academic and policy perspective.

[Insert Figure 1, Figure 2 and Table 1]

Based on their investment targets, funds can be classified as equity funds, bond funds, money market funds, balanced funds or alternative funds. As equity funds and bond funds account for more than $70 \%$ of funds' total net assets and the data for other kinds of funds are more limited, we focus on sudden stops in equity and bond fund flows in this research. We address the following research questions: (i) How have sudden stops in fund flows evolved over time and across countries? (ii) Are they mostly determined by domestic (pull) factors or global (push) factors? (iii) Are the drivers of sudden stops the same in advanced and emerging countries? and (iv) What are the determinants of the magnitude of sudden stops? We use data for fund flows into 65 advanced and emerging countries from January 2000 (2008) to June 2015. Whereas most studies on sudden stops employ annual or quarterly data, we use monthly data from the EPFR Global Database. This allows us to estimate the timing of sudden stops more precisely.

We identify four waves of sudden stops in equity flows. The first wave was in 2000-2001, while the second wave occurred in 2007-2009 when the world was hit by the global financial crisis. The third and fourth waves were in 2011-2012 and in 2014-2015. We identify three waves of sudden stops in bond flows, which coincide with the last three waves for equity flows (our data for bond flows start later than those for equity flows). Compared to sudden stops in net capital flows, we find that sudden stops in fund flows are much more clustered. The peaks of sudden stops in fund flows are earlier than those of net capital flows, which is in line with the argument that fund flows respond swiftly to shocks and are more susceptible to reversal when investors get new information (Levchenko and Mauro, 2007; Agosin and Huaita, 2012). Our results suggest that that global, contagion and domestic factors are all important in determining the likelihood of sudden stops. However, these factors are much more important in determining sudden stops in equity flows in advanced countries than in emerging countries. For sudden stops in bond flows, contagion and global variables are important drivers both in advanced and emerging countries. We also find that the magnitude of sudden stops is primarily determined by global and contagion factors.

Our contribution to the literature is threefold. First, to the best of our knowledge this is the first paper investigating sudden stops in equity and bond fund flows. Second, this paper 
presents new evidence on the drivers of the magnitude of sudden stops in fund flows. Third, our results have some interesting policy implications. For instance, they suggest that financial openness in emerging countries may reduce the likelihood of sudden stops in bond flows (but not in equity flows), but it has no effect on the magnitude of sudden stops.

The remainder of this paper is structured as follows. Section 2 summarizes related studies. After introducing the data employed, section 3 describes the identification of sudden stops in fund flows and presents their evolution and characteristics. Section 4 provides details of the models used. Sections 5 and 6 report our empirical results for the determinants of the occurrence of sudden stops and their magnitude, respectively. Section 7 offers some concluding remarks.

\section{Related literature}

\subsection{Identification of sudden stops}

Several methods have been developed to identify a sudden stop episode. The first method only considers changes of capital flows. For example, Calvo et al. (2004) consider a period as a sudden stop if it contains at least one observation for which the year-on-year fall in capital flows is at least two standard deviations below its sample mean. The episode starts when the annual change in capital flows falls one standard deviation below the mean for the first time and ends once the annual change in capital flows exceeds one standard deviation below its sample mean. Bordo et al. (2010), Rothenberg and Warnock (2011), Cowan and Raddatz (2013) and Zhao et al. (2014) apply a similar method.

The second method is based on annual changes of capital flows and their size in relation to GDP. For example, Guidotti et al. (2004) identify a sudden stop episode when the capital account contraction is larger than one standard deviation below its sample mean and the capital account contraction exceeds 5\% of GDP. Levchenko and Mauro (2007), Cowan et al. (2008), Agosin and Huaita (2012), Calderón and Kubota (2013) and Cowan and Raddatz (2013) follow a similar method. ${ }^{2}$

\subsection{Determinants of sudden stops and their consequences}

Several studies examine the determinants of sudden stops (cf. Calvo et al., 2008; Bordo et al., 2010; Agosin and Huaita, 2012; Forbes and Warnock, 2012; Calderón and Kubota, 2013). Cavallo and Frankel (2008) and Bordo et al. (2010) find that trade openness reduces the

\footnotetext{
${ }^{2}$ A less frequently applied method uses economic performance as one of the criteria to identify sudden stops; see, for example, Calvo et al. (2004; 2008).
} 
likelihood of a sudden stop. Calvo and Reinhart (2000) argue that capital controls exert little influence on the prevention of sudden stops. In line with this view, Edwards $(2004,2007)$ finds that capital account restrictions cannot reduce the probability of sudden stops. However, once a sudden stop occurs countries with higher capital mobility have a stronger decline of economic growth, while countries with higher trade openness suffer less.

While earlier studies focus on sudden stops defined on the basis of net capital flows, some recent studies break net capital flows into capital inflows (changes in the stock of international liabilities of domestic residents) and capital outflows (changes in the stock of international assets of domestic residents). For example, Cowan et al. (2008) classify sudden stops into three categories: outflow-driven sudden stops, inflow-driven sudden stops, and mixed cases. They conclude that inflow-driven sudden stops are associated with larger drops in output and investments than outflow-driven sudden stops. Rothenberg and Warnock (2011) distinguish between the retreat of global investors and sudden capital flight triggered by local investors. Their results suggest that almost half of the sudden stops can be categorized as sudden capital flights and that sudden retreats of global investors have more severe economic effects, such as greater economic slowdowns and sharper currency appreciation, than sudden capital flights. Calderón and Kubota (2013) investigate the determinants of inflow- and outflow-driven sudden stop episodes separately. Using quarterly gross capital flows data for 99 countries from 1970 to 2010, they conclude that foreign investors are more sensitive to push factors than pull factors, and that they tend to pull their funds out of countries with poor economic performance. Our work is related to these studies as we focus on sudden stops in one particular type of capital flows, namely equity and bond fund flows.

A few studies report that sudden stops generally come after surges, which are defined as exceptionally large capital inflows (Ghosh et al., 2014). For example, using data for 42 emerging economies in the period 1976 to 2003, Agosin and Huaita (2012) find that a surge in capital flows has predictive power for future sharp contractions in capital flows. Sula (2010) comes to a similar conclusion using annual data of 38 emerging market economies between 1990 and 2003. We take surges into account in our analysis.

Some studies suggest that the propagation of sudden stops to the real economy is dependent on countries' economic characteristics. For example, Edwards (2004) argues that flexible exchange rates are shock absorbers. Furthermore, financial openness may worsen the impact of sudden stops (Edwards, 2007). Based on industry-level data of 45 developed and emerging countries from 1975 to 2005, Cowan and Raddatz (2013) conclude that industries with higher external finance dependence tend to decline significantly during a sudden stop, 
especially in less financially developed countries. Our work is related to these studies, as we also examine the magnitude of sudden stops. Arguably, the larger the magnitude of a sudden stop, the larger its economic impact will be.

\subsection{Literature on fund flows}

Papers focusing on fund flows can be divided into three categories. The first group of studies focuses on the fund level. For example, Raddatz and Schmukler (2012) investigate the characteristics of investments at the fund level. They conclude that during the global financial crisis, both investors in and managers of funds adjusted their investments substantially.

The second group consists of studies focusing on fund flows into and out of countries and their determinants. For instance, based on weekly fund flow data for 50 countries from October $12^{\text {th }}, 2005$ to November $22^{\text {th }} 2010$, Fratzscher $(2012)$ analyzes whether push and/or pull factors drive fund flows (but he does not examine sudden stops in fund flows). He finds that global shocks exert a larger effect than domestic factors. Puy (2016) concludes that international portfolio flows exhibit strong cyclical behavior at the world level. Obviously, these papers are strongly related to our work. But instead of analyzing the drivers of fund flows, we examine what drives the occurrence and magnitude of sudden stops in equity and bond fund flows.

The third group of studies examines the relationship between fund flows and other variables. For instance, Wei et al. (2010) examine international funds' reactions to IMF program announcements and conclude that the Fund restored investor confidence during crises. Jinjarak et al. (2011) analyze the relationship between international portfolio flows and returns on equity and bond funds. They conclude that international fund investments are positively associated with contemporaneous and past market returns. Li et al. (2015) investigate the relationship between fund flows and domestic business cycles by calculating the concordance index of the two series. They find that fund flows are pro-cyclical ahead of the business cycle, and counter-cyclical contemporaneously and after the business cycle.

\section{Sudden stops of international fund flows: identification and characteristics}

\subsection{Data on fund flows}

The data used in this paper is from EPFR Global, which tracks the asset allocations of a large number of international funds. Most funds covered by EPFR are domiciled in advanced countries. Jotikasthira et al. (2012) and Moussavi (2014) show that EPFR portfolio flows and balance-of-payments data closely match. Several previous studies have employed this 
database as well (cf. Hsieh et al., 2008; Wei et al., 2010; Jinjarak et al., 2011; Fratzscher, 2012; Raddatz and Schmukler, 2012; Yeyati and Williams, 2012; Li et al., 2015; and Puy, 2016).

Based on data sourced directly from managers or administrators, EPFR Global combines fund flows (the money moving into or out of a fund) and funds' country allocations (the fund investment into specific countries) to provide data on the fund flows into a specific country. Sudden stops of fund flows are identified using these country flows. The data have been cleaned as follows. First, we exclude countries with less than 24 continuous observations and countries with an estimated allocation of less than 5 million US dollars. Second, we exclude countries lacking macroeconomic data. Our final dataset consists of 65 countries, of which 41 are advanced and 24 are emerging countries. The high number of advanced countries reflects that financial markets in these countries are more mature and therefore attract more fund investments than those in emerging countries. The countries in our sample are listed in Appendix 1; the time span for regression analysis runs from January 2000 to June 2015 for equity flows and January 2008 to June 2015 for bond flows.

\subsection{Identifying sudden stops}

To capture the "abrupt and major reduction in capital inflows to a country that has been receiving large volumes of fund flows", we employ the first method introduced in section 2 to define sudden stops. ${ }^{3}$ Following Calvo et al. (2004) and Forbes and Warnock (2012), we define the start of a sudden stop episode when the year-on-year change of fund flows (in US dollars) is one standard deviation below the sample mean and eventually reaches two standard deviations below the sample mean. A sudden stop ends when the annual changes are above one standard deviation below its sample mean. We proceed as follows. The original monthly fund flows (in US dollars) is labeled as $P_{t}$, and the fund flows scaled by $A U M$ is labeled as $S_{t}$. To exclude seasonal influences, we define $C_{t}$ as the 12-months moving sum of lagged values in fund flows, and then compute the annual year-over-year changes in $C_{t}$, labeled as $\Delta\left(C_{t}\right)$

$$
\begin{gathered}
C_{t}=\sum_{i=0}^{12} P_{t-i}, t=1,2, \ldots, N . \\
\Delta\left(C_{t}\right)=C_{t}-C_{t-12}, t=13,14, \ldots, N .
\end{gathered}
$$

\footnotetext{
3 We also applied the second method. This yields similar conclusions (results available on request).
} 
Next, we calculate the rolling means and standard deviations of $\Delta\left(C_{t}\right)$ over the last 24 months. If $\Delta\left(C_{t}\right)$ is one standard deviation below its 24-months rolling mean and reaches two standard deviations below the rolling mean for at least one month, the period is identified as a sudden stop episode. The episode ends when $\Delta\left(C_{t}\right)$ increases to one standard deviation below its 24-months rolling mean.

Figure 3 illustrates the identification of sudden stops for the case of Argentina. The black solid line shows $\Delta\left(C_{t}\right)$. The gray solid line is the 24-months rolling mean of $\Delta\left(C_{t}\right)$. The gray dashed lines show the one and two standard deviation(s) below the mean, respectively. If $\Delta\left(C_{t}\right)$ falls below the upper dashed line and drops to the lower dashed line for at least one month, we identify a sudden stop; the episode ends when $\Delta\left(C_{t}\right)$ crosses the upper dashed line. The shaded areas show the sudden stop episodes identified according to our method.

\section{[Insert Figure 3]}

We apply this method to fund flows in 65 countries and identify sudden stops from January 2000 (2008) to June 2015 (the underlying fund flow data start four years earlier). Table 2 presents the number of months and the percentages of sudden stops and Figure 4 describes the percentage of countries experiencing sudden stops in equity flows and bond flows. We reach the following conclusions.

Sudden stops of fund flows show a high degree of co-movement across countries, which is consistent with Puy's (2016) findings. As shown in Figure 4, there are four waves of sudden stops in equity flows and three waves of sudden stops in bond flows. For equity flows, the first wave was in 2000-2001 following the burst of the dot.com bubble and the 9/11 attacks. The second wave occurred between 2007 and 2009 when the Global Financial Crisis (GFC) hit the world. The third and fourth waves were in 2011-2012 and 2014-2015. For bond flows, given the data availability, we only identify sudden stops after 2008. We identify three waves of sudden stops in bond flows, which largely coincide with the last three waves of sudden stops in equity flows. We also find that sudden stops in bond flows are more clustered than those in equity flows; more than $80 \%$ of the countries in our sample experience sudden stops in bond flows in waves, whereas this percentage is around $50 \%$ for sudden stops in equity flows.

Table 2 reports summary statistics of sudden stops in fund flows for the full sample as well as for different country groups. We identify a total of 2007 sudden stops in equity flows 
(almost 20\% of all country-year observations) and 1359 sudden stops (almost 30\%) in bond flows. Panel B in Table 2 shows that in the period 2004-2010, more than 23\% of the total number of country-months observations experienced equity flow sudden stops, whereas $24 \%$ experienced sudden stops in bond flows. During the period 2011-2015, more countries experienced sudden stops in bond flows. The percentage of sudden stops in bond (equity) flows is $32(20) \%$.

Advanced countries are more likely to experience a sudden stop in equity flows, while emerging countries are more inclined to experience a sudden stop in bond flows. One possible reason is that advanced countries attract larger amounts of equity fund investments due to their mature financial markets. Many emerging countries exert restrictions on cross-border investments in equity markets.

Sudden stops of fund flows are unevenly distributed across regions. As shown in Panel $\mathrm{C}$ of Table 2, countries in Northern America and Western Europe are most likely to witness sudden stops in equity flows. Meanwhile, emerging and developed Asia are also experiencing more sudden stops in equity flows, probably because they are attractive for fund investments due to their promising economic growth prospects (Gelos, 2011). For bond flows, areas with more developing economies are more prone to witness sudden stops, including Emerging Asia, Developed Asia, Middle East and Africa, and Latin America.

Next, we examine differences across exchange rate regimes. To classify countries we use the de facto classification of exchange rate regimes developed by Reinhart and Rogoff (2004) and updated by Ilzetzki et al. (2008). These authors classify exchange rate regimes in 6 categories. ${ }^{4}$ We classify countries into regime 1 to regime 4 (no countries in our sample are classified in regime 5 and regime 6 in 2010), where a higher number indicates a more flexible regime. Panel D in Table 2 suggests that countries with a flexible exchange rate regime are more likely to experience sudden stops (almost $22 \%$ of the total number of country-months observations are classified as sudden stops in equity flows, while $24 \%$ are classified as sudden stops in bond flows).

\footnotetext{
4 Regime 1 includes four exchange rate arrangements: no separate legal tender, pre-announced peg or currency board arrangement, pre-announced horizontal band that is narrower than or equal to $+/-2 \%$, and de facto peg. Regime 2 includes four exchange rate arrangements: pre-announced crawling peg, pre-announced crawling band that is narrower than or equal to $+/-2 \%$, de facto crawling peg, and de facto crawling band that is narrower than or equal to $+/-2 \%$. Regime 3 contains regimes with a pre-announced crawling band that is wider than or equal to $+/-2 \%$, with a de facto crawling band that is narrower than or equal to $+/-5 \%$, moving band that is narrower than or equal to $+/-2 \%$ (i.e., allows for both appreciation and depreciation over time), and with managed floating. Regime 4 captures exchange rates that are freely floating. Regime 5 captures free falling exchange rates and Regime 6 indicates a dual market in which parallel market data is missing.
} 
[Insert Figure 4 and Table 2]

\subsection{Sudden stops and the business cycle}

It seems that sudden stops tend to cluster during economic downswings. To further examine the relationship between sudden stops and business cycles, we date the turning points of (seasonally adjusted) industrial production based on the algorithm developed by Bry and Boschan (1971). Here, we identify the time period between peak and trough as economic contraction and the time period between trough and peak as economic expansion. As shown in Figure 5, most sudden stops in fund flows coincide with economic contractions. The figure also suggests that peaks in sudden stops in fund flows tend to be followed by peaks in economic contraction. For example, the number of countries experiencing sudden stops reached its peak in 2006-2007, while the number of countries experiencing economic contractions peaked in 2008-2009.

\section{[Insert Figure 5]}

\subsection{Comparison of sudden stops in fund flows and net capital flows}

To further investigate the characteristics of sudden stops in fund flows, we employ the same method introduced in section 3.2 to identify sudden stops in portfolio flows and net capital flows. The data is derived from BoP statistics. Quarterly data from 1996Q1 to 2015Q2 is used to identify sudden stops in net capital flows. We aggregate the monthly fund flows to quarterly frequency and compare these with capital flows (see Figure 6). We reach the following conclusions.

First, the waves of sudden stops in net capital flows coincide with waves of sudden stops in fund flows, especially during the global financial crisis in 2008-2009, the European sovereign debt crisis in 2011-2012 and the post-crisis period in 2014-2015. This implies that countries cannot rely on other types of capital flows when they are confronted with a sudden stop in fund flows.

Second, sudden stops in fund flows are more clustered than those in net capital flows, especially in the latest two waves. For example, during 2011Q4, more than $80 \%$ of countries experienced a sudden stop in bond flows and around 50\% countries experienced a sudden stop in equity flows, whereas the percentage of countries witnessing sudden stops in capital flows was around $10 \%$.

Third, the peaks of sudden stops in fund flows tend to be prior to sudden stops in capital flows. For example, when the global economy was hit by the US subprime crisis, the peak of 
sudden stops in equity flows occurred in 2008Q3, whereas the peak of sudden stops in capital flows was in 2009Q1. During 2001-2012, around 50\% of the countries experienced a sudden stop in equity flows in 2011Q4. However, the peak of sudden stops in capital flows occurred in 2012Q2, and 14\% countries witnessed a sudden stop in this wave. These results are consistent with the argument that fund flows respond swiftly to shocks and are more susceptible to reversal when investors get new information (Levchenko and Mauro, 2007; Agosin and Huaita, 2012).

\section{[Insert Figure 6]}

\section{Models and method}

\subsection{Models}

In line with Calvo et al. (2008), Calderón and Kubota (2013) and Ghosh et al. (2014), we use a probit model to examine the determinants of the occurrence of sudden stops in funds flows. The following model is estimated:

$$
\operatorname{Pr}\left(S_{i, t=1}\right)=F\left(B_{G}^{\prime} X_{t-1}^{\text {Global }}+B_{C}^{\prime} X_{i, t-1}^{\text {Contagion }}+B_{D}^{\prime} X_{i, t-1}^{\text {Domestic }}\right)
$$

where $S_{i, t}$ is a dummy variable which takes value one when there is a sudden stop in

country $i$ at time $t ; X_{t-1}^{\text {Global }}, X_{i, t-1}^{\text {Contagion }}$ and $X_{i, t-1}^{\text {Domestic }}$ are vectors containing global, contagion, and domestic variables (explained below), respectively; while $B_{G}, B_{C}, B_{D}$ are the vectors of estimated parameters. $F($.$) is the probit function, which is assumed to be a$ cumulative function of the standard normal distribution. To limit reverse causality, all explanatory variables are lagged one period (cf. Forbes and Warnock, 2012; Calderón and Kubota, 2013). Following Ghosh et al. (2014), we include region dummies to control for region-specific effects.

As a robustness check, we also estimate complementary log-log (cloglog) models (cf. Forbes and Warnock, 2012; Calderón and Kubota, 2014). The cloglog function is asymmetric, which is well suited for irregular events like sudden stops. $F($.$) for the cloglog model is$ $F(z)=1-e^{-e^{z}}$. We also use random effect probit models in the sensitivity analysis.

To estimate the determinants of the magnitude of sudden stops, we use an OLS model (cf. Ghosh et al., 2014). The estimated model is as follows:

$$
-K_{i, t / S_{i, t=1}}=B_{G}^{\prime} X_{t-1}^{\text {Global }}+B_{C}^{\prime} X_{i, t-1}^{\text {Contagion }}+B_{D}^{\prime} X_{i, t-1}^{\text {Domestic }}+\varepsilon_{i, t}
$$


where $K_{i, t / S_{i, t=1}}$ are fund flows (scaled by $A U M$ ) into country $i$ at time $t$, conditional on the occurrence of a sudden stop. We change the sign of the amount of fund flows (negative numbers become positive and vice versa) so that higher values indicate larger sudden stops. $X_{t-1}^{\text {Global }}, X_{i, t-1}^{\text {Contagion }}$ and $X_{i, t-1}^{\text {Domestic }}$ are vectors of (lagged) global, contagion and domestic variables, respectively; $\varepsilon_{i, t}$ is the random error term. In line with Ghosh et al. (2014), we add region dummies.

\subsection{Definition of variables}

Following the literature on the determinants of sudden stops of capital flows (Calvo et al., 2008; Agosin and Huaita, 2012; Forbes and Warnock, 2012; Calderón and Kubota, 2013 and Cowan and Raddatz, 2013), and following studies on the driving factors of fund flows (Fratzscher, 2012 and Puy, 2016), we consider several potential determinants of sudden stops of fund flows, which can be divided into global, domestic, and contagion variables.

\subsubsection{Global variables}

Global variables capture external conditions, which are largely beyond the control of recipient countries (and which are therefore often referred to as push factors), such as global growth, global interest rates, global equity returns, global liquidity risk, global risk aversion, commodity price shocks, macroeconomic policy uncertainty and economic news shocks.

Following Calderón and Kubota (2013) and Puy (2016), global interest rates and growth are proxied by the average short-term interest rates and the industrial production growth rate in the US, the UK and Japan. Likewise, global equity returns are proxied by average monthly stock returns in the US, the UK and Japan.

We use the TED spread, which is calculated as the difference between the three-month LIBOR and the three-month T-bill interest rate, as a measure of global liquidity risk and counterparty risk. A higher TED spread indicates a liquidity squeeze and an increase of counterparty risk (Fratzscher, 2012). In line with Forbes and Warnock (2012), Fratzscher (2012) and Calderón and Kubota (2013), we measure global risk aversion using the Chicago Board Options Exchange (CBOE) volatility index (VIX). To capture the influence of changes in global liquidity risk and global risk aversion, the first differences of the TED spread and the VIX are employed in our model. We also include movements in commodity prices as a global market shock. Following Ghosh et al. (2014), it is measured as the log difference between the actual and trend values of the Standard \& Poor's/Goldman Sachs Commodity Index (GSCI). 
Further, we include Baker's et al. (2013) US policy uncertainty index as a global variable. ${ }^{5}$ This variable has been used in recent research on the drivers of capital flows (cf. Calderón and Kubota, 2014; Gauvin et al., 2014). Higher values indicate more policy uncertainty. We use the first difference of this series. Finally, we also include the Citigroup Economic Surprises Index (CESI) in the G10 countries, which is defined as a weighted historical standard deviation of data surprises. Positive values of CESI indicate that economic data are better than expected by markets (Puy, 2016). As this variable is available from January 2003 onwards, we only include it in the sensitivity analysis.

\subsubsection{Domestic variables}

Domestic variables capture characteristics of recipient countries (and which are therefore also called pull factors). We consider macroeconomic fundamentals, domestic financial market performance, trade and financial openness, as well as some policy indicators.

Sound and stable macroeconomic fundamentals reduce the likelihood of a sudden stop (Calderón and Kubota, 2013). In line with Fratzscher (2012), we therefore include the growth rate of domestic industrial production. Like Puy (2016), we calculate the 5-year moving standard deviation of industrial production growth as a measure of output volatility. As the time span for output volatility is short, we include this variable only in the sensitivity analysis. CPI inflation is included as a proxy for monetary stability (Calderón and Kubota, 2013). Short-term interest rates are also included because international capital flows are sensitive to interest rate differentials (Fratzscher, 2012; Gauvin et al., 2014). In addition, Cowan and Raddatz (2013) point out that the accumulation of reserves can prevent sudden stops and provide liquidity in case a sudden stop occurs. Therefore, the variable international foreign reserves (as \% of GDP) is also included as a potential explanatory factor (see also Edwards, 2007; Fratzscher, 2012). We also consider the fiscal balance (as \% of GDP) and the current account balance (as \% of GDP) in our model; as these variables are available at annual frequency we only include them in the sensitivity analysis.

Further, we include domestic equity returns, because some previous studies report that higher equity returns tend to decrease the likelihood of a sudden stop (Fratzscher, 2012; Gauvin et al., 2014). We also include the expected real effective exchange rate depreciation (Ghosh et al., 2014 and Calderón and Kubota, 2014), which is calculated by subtracting each country's real effective exchange rate from its corresponding HP trend. ${ }^{6}$ Domestic credit

\footnotetext{
${ }^{5}$ Data available online at: www.PolicyUncertainty.com.

${ }^{6}$ We first adjust the seasonality of series with Census X-12 multiplicative method (SA) and then use HP filter
} 
growth is included following Edwards (2007), Fratzscher (2012) and Cowan and Raddatz (2013).

We add several measures of openness to examine the role of openness in determining sudden stops. Specifically, we consider trade openness, which is calculated as the sum of imports and exports over GDP (cf. Edwards, 2007; Fratzscher, 2012 and Calderón and Kubota, 2014), and financial openness, which is calculated as the ratio of net capital flows to GDP (cf. Calderón and Kubota, 2013). We also use the KAOPEN index of Chinn and Ito (2006) as a proxy for financial openness in the sensitivity analysis as this index is widely used in the literature on capital flows (cf. Lambert et al., 2011; Forbes and Warnock, 2012 and Fratzscher, 2012). We also consider financial integration measures developed by Lane and Milesi-Ferretti (2003; 2007); see also Calvo et al. (2008) and Fratzscher (2012). FDI integration is calculated as the ratio of the stock of FDI assets and FDI liabilities to GDP. In line with Fratzscher (2012), we regress FDI integration on trade openness, and the residual is used as a measure of FDI integration. Similarly, portfolio integration is calculated as the stock of portfolio assets and liabilities scaled by GDP.

As pointed out before, the exchange rate regime in place may affect the likelihood of a sudden stop (cf. Calderón and Kubota, 2013; 2014). We use the classification of exchange rate regimes as described in section 3.2. Because this data is available until 2010, we consider this variable only in the sensitivity analysis. In addition, the quality of institutions may affect fund flows (Ghosh et al., 2014). Therefore, we include Standard \& Poor's sovereign rating and the International Country Risk Guide (ICRG) political risk index. The political risk index is calculated to assess the political stability of each country; a higher number indicates lower political risk.

\subsubsection{Contagion variables}

Some recent studies report so-called contagion effects for sudden stops (cf. Kaminsky et al., 2001; Forbes and Warnock, 2012). We follow these studies and consider contagion through geography. Specifically, in line with Forbes and Warnock (2012) and Calderón and Kubota (2013), geographical contagion is considered by using a dummy variable, which equals one in period $t$ if at least one country in the same region has a sudden stop in period $t-1$.

Agosin and Huaita (2012) and Sula (2010) present evidence that surges have predictive power for sudden stops. Large capital inflows are argued to deteriorate the economic 
fundamentals of the recipient country and therefore to increase the probability of a sudden stop. Following Forbes and Warnock (2012) and making it comparable with sudden stops, we identify the start of a surge episode when the year-on-year change of fund flows (in US dollars) is one standard deviation above the sample mean and eventually reaches two standard deviations above the sample mean. A surge ends when the annual changes are below one standard deviation above its sample mean. To examine the predictive power of a surge on sudden stops, we include surges using a dummy variable, which takes value one at time $t$ if the country experiences a surge in the period $t-12$ to $t$ - 1 and which is zero otherwise.

A detailed description of all variables and their data sources is provided in Appendix 2. All variables are winsorized at the lower 1\% level and upper 99\% level to avoid any bias due to outliers.

As some data is missing for a few countries (Cyprus, Egypt, Estonia, Jordan, Morocco, Nigeria, Oman, Panama, Qatar, Saudi Arab, Slovenia, Sri Lanka and Taiwan), we delete them in our estimations. Therefore, the sample in this part of our analysis includes 52 countries, including 34 advanced countries and 18 emerging countries. The time span is from January 2000 (2008) to June 2015. Appendix 3 provides summary statistics.

Before estimating the model, we examine the correlation of the variables in Appendix 4; Appendix 4A provides a correlation matrix for the global variables, and Appendix 4B shows the correlation of the domestic and contagion variables. Because the variable KAOPEN is highly correlated with the political risk index, we drop this variable when we include KAOPEN.

\section{Occurrence of sudden stops}

This section reports results for the determinants of the occurrence of sudden stops. Section 5.1 presents the outcomes for the baseline model, and section 5.2 compares advanced and emerging countries. Section 5.3 offers a sensitivity analysis.

\subsection{Baseline model}

We examine whether global, domestic, and contagion variables are related to the occurrence of sudden stops in fund flows. Table 3 shows our baseline regression results for sudden stops in equity flows (columns (1)-(4)) and bond flows (columns (5)-(8)). The dependent variable is a binary variable, which takes value one if a sudden stop occurs and which is zero otherwise. In columns (1) and (5), we only include global variables, and we add contagion variables in columns (2) and (6). Next, we add domestic variables in columns (3) and (7) and further 
examine non-linear effects of portfolio integration in columns (4) and (8), respectively. We check whether the order in which we include variables affects our findings and conclude that this is not the case (see Appendix 5 for details).

The results suggest that the occurrence of sudden stops in fund flows is significantly related to several push factors. Adverse global shocks tend to make countries more prone to sudden stops. Specifically, recipient countries are more likely to experience sudden stops during periods with low global growth, low global equity returns, and high global interest rates. This result is consistent with the findings of Forbes and Warnock (2012) and Calderón and Kubota (2013). Although global risk aversion is positively related with sudden stops in net/gross capital flows (Forbes and Warnock, 2012; Calderón and Kubota, 2013), our results suggest it is negatively related to sudden stops in fund equity flows and bond flows. This may be due to the characteristics of fund investments. Investors tend to invest more in global funds to diversify their risks when financial volatility increases. The results for different samples of countries below suggest that this negative effect is strongest for advanced economies, which provides support for this argument. Commodity price shocks increase the probability of sudden stops in fund flows.

Although most global factors are significant, their explanatory power is limited. The pseudo R-squared is almost $6 \%$ for equity flows and around $9 \%$ for bond flows when we only include global variables. Likewise, the sensitivity (i.e. the fraction of sudden stops that is correctly predicted) is rather low.

We also find that the contagion variables are significant, both for equity flows and for bond flows. Countries are more likely to experience a sudden stop when there is another country in the same region that experienced a sudden stop. In addition, a surge episode has predictive power for sudden stops. This finding is consistent with the results reported by Sula (2010) and Agosin and Huaita (2012). The pseudo R-squared increases to $22 \%$ for equity flows and $32 \%$ for bond flows after adding the contagion variables (column (2) and column (6)). Likewise, the sensitivity increases substantially.

Domestic variables exert a different influence on sudden stops in equity flows and bond flows. The probability of a sudden stop in equity flows is negatively related to domestic CPI inflation, equity returns, expected REER depreciation and trade openness. The result for trade openness is consistent with previous studies on sudden stops in net/gross capital flows (Cavallo and Frankel, 2008; Bordo et al. 2010). The coefficient on credit growth is positive. Rapid expansion of domestic credit may lead to financial instability and therefore to sudden stops. To examine whether the relationship between portfolio integration and sudden stops is 
non-linear, we follow Calvo et al. (2008) and include a quadratic term of portfolio integration. Column (4) provides evidence for a non-linear relationship: a country will benefit from portfolio integration at low levels of integration, but after some point integration increases the likelihood of a sudden stop. Political risk is not significantly related to sudden stops in equity flows.

In our model for sudden stops in bond flows, the coefficient on domestic CPI inflation is positive. Similar to sudden stops in equity flows, trade openness tends to decrease the likelihood of a sudden stop in bond flows. FDI integration is also negatively related with sudden stops in bond flows; but portfolio integration plays an opposite role. The coefficient on political risk is positive. This is a somewhat puzzling result as it implies that countries with a stable political environment are more prone to experience sudden stops. However, this may reflect that only politically stable countries can attract global bond investments and may therefore be prone to sudden stops. (As shown below, the coefficient on political risk in the sample of emerging countries is negative in the model for sudden stops in equity flows.) Other domestic variables play only a limited role in sudden stops in bond flows.

Adding the domestic variables hardly makes the pseudo R-squared to increase, suggesting that domestic factors only play a marginal role in driving sudden stops in fund flows. However, adding domestic factors increases the fraction of sudden stops that is correctly predicted (sensitivity), notably for sudden stops in equity flows (the sensitivity increases from $26 \%$ to $33 \%$ after adding domestic variables).

The percentage of correctly predicted sudden stops and non-sudden stops is around $80 \%$ for equity flows and $77 \%$ for bond flows. Table 4 presents the marginal effects of all the explanatory variables in detail.

[Insert Table 3 and Table 4]

\subsection{Advanced vs. emerging countries}

Following the same set-up as Table 3, we estimate the model for advanced and emerging countries separately. Panel A of Table 5 shows the results for sudden stops in equity flows. We draw the following conclusions. First, global factors play a more important role in advanced countries than in emerging countries. Although the sign of the indicators is the same, most global push indicators become insignificant for the sample of emerging countries, especially after adding domestic variables.

Second, domestic factors are also more significant in advanced countries than in 
emerging countries. Most domestic variable are significant in advanced economies except for industrial production growth, the short-term interest rate and FDI integration. The inflation rate is negatively related to sudden stops in advanced countries, but it is significantly positively related to sudden stops in emerging countries. One possible reason is that inflation in emerging countries is more volatile. High inflation in emerging countries is related to deteriorating economic fundamentals and may, therefore, lead to sudden stops. Trade openness and financial openness are not significantly related with sudden stops in emerging countries. In addition, political risk index is positively related with sudden stops in advanced countries whereas it is negatively related with sudden stops in emerging countries.

In sum, sudden stops in equity flows in advanced countries are more influenced by global and domestic factors, while in emerging countries they play a relatively limited role. The percentage of correctly predicted sudden stops and non-sudden stops is around $80 \%$ both for advanced and for emerging countries.

For bond flows, the results are different. As shown in Panel B of Table 5, several global variables are significantly related to the occurrence of a sudden stop in advanced countries and emerging countries. Also the contagion variables are significant in the models for both subsamples. Regarding domestic variables, the coefficient on trade openness is only significant for advanced countries, whereas financial openness only turns out to be significant for emerging countries. FDI integration is significantly related to sudden stops in bond flows in both subsamples, while credit growth and political risk are only significant in the model for advanced countries.

In sum, contagion and global variables are the most important drivers of sudden stops in bond flows in advanced and emerging countries. Domestic variables hardly increase the pseudo R-squared for sudden stops in bond flows. The fraction of sudden stops that are correctly predicted (sensitivity) is higher for bond flows in emerging countries (79\%) than in advanced countries (48\%).

\section{[Insert Table 5]}

\subsection{Sensitivity analysis}

We perform a range of sensitivity tests to check the robustness of our estimation results. First, we employ a complementary log-log model (cloglog model) to capture the asymmetric distribution of sudden stops (Forbes and Warnock, 2012; Calderón and Kubota, 2014). The results are quite similar to those of our baseline probit model shown in Table 3 (see column (1) 
in Table 6).

Second, in column (2) of Table 6, we use random effects to estimate the model for sudden stops in equity flows. The findings suggest that the results for our baseline model are quite robust. In column (3), we replace "policy uncertainty in United States" by "policy uncertainty in Europe Union" and find that it is not significant. In column (4), we define the geography contagion dummy variable to be equal to one if at least $50 \%$ of the countries in the same region have a sudden stop in period t-1. It is still significant. In column (5), we include the Citigroup Economic Surprise Index (CESI). The results suggest that better than expected news decreases the likelihood of sudden stops. In columns (6) and (7) we include several additional domestic variables, including output volatility, fiscal balance (as \% of GDP), current account balance (as \% of GDP), KAOPEN, and the exchange rate regime. The results show that a higher current account surplus reduces the risk of a sudden stop. In addition, we find that countries with a more flexible exchange rate regime are more likely to experience sudden stops, which is consistent with our preliminary analysis in section 3.2. This may be due to the fact that two thirds of our sample consists of advanced countries, and most of them have a flexible exchange rate regime.

[Insert Table 6]

Finally, we compare the determinants of fund flow sudden stops and net capital flow sudden stops examined by Calderón and Kubota (2013) and Forbes and Warnock (2012) (Appendix 6). As Appendix 6 shows, we consider many more explanatory variables than current research on net capital flows. We conclude that adverse global shocks (such as low global growth, low global equity returns, and high global interest rates) tend to make countries more prone to both fund flow sudden stops and net capital flow sudden stops. Geography contagion plays an important role in the transmission of sudden stops, both for fund flows and net capital flows. Although global risk aversion is positively related with sudden stops in net/gross capital flows, our results suggest that it is negatively related to sudden stops in equity flows and bond flows, which may be due to the characteristics of fund investments.

\section{Magnitude of sudden stops}

Finally, we investigate the drivers of the magnitude of sudden stops for equity flows and bond flows. The dependent variable in the baseline model is the change of fund flows (scaled by 
$A U M)$ conditional on sudden stops, where negative (positive) numbers have been transformed into positive (negative) ones. Table 7 reports the estimation results. ${ }^{7}$ In columns (1) and (4) only global factors are included. In columns (2) and (5) contagion variables are added, while in columns (3) and (6) domestic variables are taken up as well.

The following conclusions can be drawn from Table 7. First, the magnitude of sudden stops is especially determined by global push factors. Most global variables considered are significant. The magnitude of sudden stops in fund flows is positively related to global interest rates and negatively related to global equity returns. Although global risk aversion decreases the probability of sudden stops in fund flows, it increases the magnitude of sudden stops once they occur. Second, some variables have a different impact on the magnitude of sudden stops in both types of funds flows. The sign of the coefficient on global liquidity risk, commodity prices and policy uncertainty is different in the models for equity and bond flows. Third, domestic variables play a limited role in determining the magnitude of sudden stops. Most of these variables are insignificant, including financial openness.

\section{[Insert Table 7]}

We also conduct several sensitivity tests for model (2). They indicate that the results as reported in Table 7 are quite robust. Appendix 7 shows the details. In column (1) of Appendix 7, we replace "policy uncertainty in the United States" by "policy uncertainty in the European Union". It turns out that policy uncertainty in the European Union is not significant in contrast to policy uncertainty in the US. In column (2), we add our proxy for economic news and find that the magnitude of sudden stops is negatively related to negative news shocks in G10 countries. Better than expected news decreases the magnitude of sudden stops. In columns (3) and (4) we add some domestic variables, including output volatility, fiscal balance (as \% of GDP), current account balance (as \% of GDP), KAOPEN and our exchange rate regime variable. The results indicate that most domestic variables only play a limited role in determining the size of sudden stops, except for the exchange rate regime. Although a flexible exchange rate regime increases the likelihood that a sudden stop occurs, it decreases the magnitude of a sudden stop. The insignificance of the coefficient on the Chinn-Ito index suggests that countries cannot reduce the magnitude of sudden stops by imposing capital account restrictions.

\footnotetext{
7 One caveat is that we are conditioning on an outcome that is explained by the same variables that are on the RHS of the equation.
} 


\section{Conclusions}

Based on monthly data of 65 countries from January 2000 (2008) to June 2015, this paper identifies the occurrence and size of sudden stops of international fund flows. Equity flows experienced four waves of sudden stops, in 2000-2001 (dotcom bust and 9/11 terrorist attacks), 2007-2009 (global financial crisis), 2011-2012 (European sovereign debt crisis) and 2014-2015. Given the data availability, we get three waves of bond flow sudden stops, which coincide with the last three waves for equity flows. We also find that sudden stops in bond flows are even more clustered than those in equity flows. Advanced countries are more likely to experience sudden stops in equity flows, whereas emerging countries are more inclined to experience sudden stops in bond flows.

We also compare the sudden stops in fund flows and sudden stops in net capital flows. We find that sudden stops in fund flows are much more clustered than those in net capital flows. The peaks of sudden stops in fund flows tend to be prior to those in capital flows.

We also investigate the drivers of the occurrence of sudden stops in fund flows. Employing probit models, we find that global factors, contagion factors, and domestic factors are all important in determining the likelihood of sudden stops. Specifically, adverse global shocks tend to make countries more prone to sudden stops. However, our results also suggest that the explanatory power of global factors is limited. Countries are more likely to experience sudden stops if their neighbors also have a sudden stop. Regarding domestic factors, more trade openness and more FDI integration reduce the likelihood of a sudden stop. When it comes to differences between advanced and emerging countries, sudden stops in equity flows in advanced countries are more influenced by global and domestic factors, while in emerging countries they play a relatively limited role. Contagion and global variables are the most important drivers of sudden stops in bond flows both in advanced and emerging countries. The fraction of sudden stops that is correctly predicted is higher in emerging countries than in advanced countries.

To analyze the magnitude of sudden stops we employ OLS models and come to the following conclusions. In contrast to the occurrence of sudden stops, we find that the magnitude of sudden stops is determined by global push and contagion factors, while domestic pull variables only play a limited role. It seems likely that the larger the magnitude of a sudden stop is, the larger its economic impact will be. However, the possible consequences of sudden stops of fund flows, although highly relevant, are beyond the scope of our paper. We therefore leave a more extensive analysis of the consequences of sudden 
stops in fund flows for future research.

\section{References}

Agosin, M.R., Huaita, F. (2012). Overreaction in capital flows to emerging markets: booms and sudden stops. Journal of International Money and Finance 31(5), 1140-1155.

Baker, S. R., Bloom, N., Davis, S.J. (2013). Measuring economic policy uncertainty. NBER Working Paper 21633. National Bureau of Economic Research.

Bohn, H., Tesar, L.L. (1996). US equity investment in foreign markets: portfolio rebalancing or return chasing? American Economic Review 86(2), 77-81.

Bordo, M.D., Cavallo, A.F., Meissner, C.M. (2010). Sudden stops: determinants and output effects in the first era of globalization, 1880-1913. Journal of Development Economics 91(2), 227-241.

Bry, G., Boschan, C. (1971). Cyclical analysis of time series: selected procedures and computer programs. NBER Technical Paper 20. National Bureau of Economic Research.

Calderón, C., Kubota, M. (2013). Sudden stops: Are global and local investors alike? Journal of International Economics 89(1), 122-142.

Calderón, C., Kubota, M. (2014). Ride the wild surf: an investigation of the drivers of surges in capital inflows. World Bank Policy Research Working Paper 6753.

Calvo, G.A. (1998). Capital flows and capital-market crises: the simple economics of sudden stops. Journal of Applied Economics 1(1), 35-54.

Calvo, G.A., Izquierdo, A., Mejia, L.F. (2004). On the empirics of sudden stops: the relevance of balance-sheet effects. NBER Working Paper 10520. National Bureau of Economic Research.

Calvo, G.A., Izquierdo, A., Mejía, L.F. (2008). Systemic sudden stops: the relevance of balance-sheet effects and financial integration. NBER Working Paper 14026. National Bureau of Economic Research.

Calvo, G.A., Reinhart, C.M. (2000). When capital inflows come to a sudden stop: consequences and policy options. In Kenen, P., Swoboda, A. (Eds.), Reforming the international monetary and financial system, Washington DC: International Monetary Fund, pp. 175-201.

Calvo, G. A., Talvi, E. (2005). Sudden stop, financial factors and economic collpase in Latin America: learning from Argentina and Chile. NBER Working Paper 11153. National Bureau of Economic Research.

Cavallo, E.A., Frankel, J.A. (2008). Does openness to trade make countries more vulnerable to sudden stops, or less? Using gravity to establish causality. Journal of International Money and Finance 27(8), 1430-1452.

Chinn, M.D., Ito, H. (2006). What matters for financial development? Capital controls, institutions, and interactions. Journal of Development Economics 81(1), 163-192.

Cowan, K., De Gregorio, J., Micco, A., Neilson, C. (2008). Financial diversification, sudden stops, and sudden starts. In Cowan, K., Edwards, S., Valdés, R.O. (Eds.), Current account and external finance, Santiago, Chile: Central Bank of Chile, pp. 159-194.

Cowan, K., Raddatz, C. (2013). Sudden stops and financial frictions: Evidence from industry-level data. Journal of International Money and Finance 32(1), 99-128.

de Mello, L., Padoan, P. C., Rousová, L. (2012). Are Global Imbalances Sustainable? Shedding Further Light on the Causes of Current Account Reversals. Review of International Economics 20(3), 489-516.

Edwards, S. (2004). Financial openness, sudden stops and current account reversals. American Economic Review 94(2), 59-64. 
Edwards, S. (2007). Capital controls, sudden stops, and current account reversals. In Edwards, S. (Ed), Capital controls and capital flows in emerging economies: policies, practices and consequences, Chicago: University of Chicago Press, pp. 73-120.

Forbes, K.J., Warnock, F.E. (2012). Capital flow waves: surges, stops, flight, and retrenchment. Journal of International Economics 88(2), 235-251.

Fratzscher, M. (2012). Capital flows, push versus pull factors and the global financial crisis. Journal of International Economics 88(2), 341-356.

Froot, K.A., O'connell, P.G., Seasholes, M.S. (2001). The portfolio flows of international investors. Journal of Financial Economics 59(2), 151-193.

Gauvin, L., McLoughlin, C., Reinhardt, D. (2014). Policy uncertainty spillovers to emerging markets-evidence from capital flows. Bank of England Working Paper 512.

Gelos, G. (2011). International mutual funds, capital flow volatility, and contagion-a survey. IMF Working Paper 1-27, International Monetary Fund.

Ghosh, A.R., Qureshi, M.S., Kim, J.I., Zalduendo, J. (2014). Surges. Journal of International Economics 92(2), 266-285.

Guidotti, P.E., Sturzenegger, F., Villar, A., de Gregorio, J., Goldfajn, I. (2004). On the consequences of sudden stops. Economia 4(2), 171-214.

Hau, H., Rey, H. (2006). Exchange rates, equity prices, and capital flows. Review of Financial Studies 19(1), 273-317.

Hsieh, S., Tai, Y.Y., Vu, T.B. (2008). Do herding behavior and positive feedback effects influence capital inflows? Evidence from Asia and Latin America. The International Journal of Business and Finance Research 2(2), 19-34.

Ilzetzki, E., Reinhart, C., Rogoff, K. (2008). The country chronologies and background material to exchange rate arrangements in the 21 st century: which anchor will hold. Mimeo.

Jinjarak, Y., Wongswan, J., Zheng, H. (2011). International fund investment and local market returns. Journal of Banking \& Finance 35(3), 572-587.

Kaminsky, G., Lyons, R., Schmukler, S. (2001). Mutual fund investment in emerging markets: An overview. World Bank Economic Review 15(2), 315-340.

Lambert, F. J., Ramos-Tallada, J., Rebillard, C. (2011). Capital controls and spillover effects: evidence from Latin-American countries. Banque de France Working Paper 357.

Lane, P.R., Milesi-Ferretti, G.M. (2003). International financial integration. IMF Staff Papers 50, 82-113.

Lane, P.R., Milesi-Ferretti, G.M. (2007). The external wealth of nations mark II: Revised and extended estimates of foreign assets and liabilities, 1970-2004. Journal of International Economics 73(2), 223-250.

Levchenko, A.A., Mauro, P. (2007). Do some forms of financial flows help protect against "sudden stops"? The World Bank Economic Review 21(3), 389-411.

Li, S., de Haan, J., Scholtens, B., Yang, H. (2015). Are international fund flows pro-or counter-cyclical? Applied Economics Letters 22(5), 378-384.

Puy, D. (2016). Mutual funds flows and the geography of contagion. Journal of International Money and Finance 60, 73-93.

Raddatz, C., Schmukler, S.L. (2012). On the international transmission of shocks: Micro-evidence from mutual fund portfolios. Journal of International Economics 88(2), 357-374.

Reinhart, C.M., Reinhart, V.R. (2008). Capital flow bonanzas: an encompassing view of the past and present. NBER Working Paper 14321. National Bureau of Economic Research.

Reinhart, C.M., Rogoff, K.S. (2004). The modern history of exchange rate arrangements: a reinterpretation. Quarterly Journal of Economics 119(1), 1-48. 
Rothenberg, A.D., Warnock, F.E. (2011). Sudden flight and true sudden stops. Review of International Economics 19(3), 509-524.

Sula, O. (2010). Surges and sudden stops of capital flows to emerging markets. Open Economies Review 21(4), 589-605.

Wei, S. J., Zhang, Z., Du, Q. (2010). Does the global fireman inadvertently add fuel to the fire? New evidence from institutional investors' response to IMF program announcements. Journal of International Money and Finance 29(4), 728-741.

Yeyati, E.L., Williams, T. (2012). Emerging economies in the 2000s: Real decoupling and financial recoupling. Journal of International Money and Finance, 31(8), 2102-2126.

Zhao, Y., de Haan, J., Scholtens, B., Yang, H. (2014). Sudden Stops and Currency Crashes. Review of International Economics, 22(4), 660-685. 